assumed to be the result of the trisomy of the distal long arm, as deletion of the terminal p13 region will have minimal effect. The meiotic mechanism whereby crossing over in an inversion loop leads to unbalanced recombinants has been discussed in a previous case. ${ }^{4}$ In only one family has a pericentric inversion of 13 produced both possible unbalanced recombinants, but one of the two examples of the trisomy $p$ recombinant died at 6 weeks and the second was terminated after diagnosis following amniocentesis. ${ }^{5}$ The family described here has a history of perinatal deaths as well as miscarriage but at least one of the stillbirths was said to have polydactyly, indicating the trisomy $q$ recombinant. A segregation analysis of 60 parents in which one of the parents was a carrier of inv(13) has shown a significant predominance of males among the viable offspring. ${ }^{6}$ This suggests a possible selection against female offspring, but most offspring of this family for three known generations have been female.

The EsD typing was kindly carried out by the MRC Human Biochemical Genetics Unit, Galton
Laboratory, London, by arrangement with Dr D A Hopkinson.

\section{References}

1 Wenger SL, Steele MW. Meiotic consequences of pericentric inversions of chromosome 13. Am J Med Genet $1981 ; 9: 275-83$.

2 Hornstein L, Soukup S. A recognisable phenotype in a child with partial duplication $13 \mathrm{q}$ in a family with $\mathrm{t}(10 \mathrm{q} ; 13 \mathrm{q})$. Clin Genet $1981 ; 19: 81-6$.

3 Noel B, Quack B, Rethoré MO. Partial deletions and trisomies of chromosome 13. Mapping of bands associated with particular malformations. Clin Genet 1976;9:593-602.

4 Escobar JI, Sanchez OMD, Yunis JJ. Trisomy for the distal segment of chromosome 13. Am J Dis Child 1974; 128:217-20.

5 Williamson EM, Miller JF, Seabright M. Pericentric inversion (13) with two different recombinants in the same family. J Med Genet 1980;17:309-12.

6 Habedank M. Familial pericentric inversion of chromosome 13 resulting in duplication $13 \mathrm{q} 22 \rightarrow$ qter. $J$ Med Genet $1982 ; 19: 227-9$.

Correspondence and requests for reprints to Ms E L Maltby, Centre for Human Genetics, University of Sheffield, Langhill, 117 Manchester Road, Sheffield S10 5DN.

\title{
Trisomy 18 phenotype in a patient with an isopseudodicentric 18 chromosome*
}

\author{
ERIC A WULFSBERG, ROBERT S SPARKES, IVANA J KLISAK, \\ AND AUDREY TENG \\ Division of Medical Genetics, Departments of Medicine, Pediatrics, and Psychiatry, \\ UCLA School of Medicine, Los Angeles, California, USA.
}

SUMMARY We report a female patient with a typical trisomy 18 phenotype who has a $46, \mathrm{XX}$, $-18,+$ isopseudodic(18)(p11) karyotype. The lack of features of the $18 p$ - syndrome suggests that a significant amount of short arm material is present and that the Turner-like features associated with $18 \mathrm{p}-$ may be determined by monosomy for $18 \mathrm{p} 11$. The phenotype-genotype correlations in abnormalities affecting chromosome 18 are reviewed.

A variety of structural abnormalities affecting chromosome 18 has been described including monosomy, ${ }^{1}$ trisomy, ${ }^{2}$ and tetrasomy ${ }^{3}$ for $18 \mathrm{p}$, as

*This study was supported in part by grants HDO5615 and HD04612 from the National Institute of Child Health and Human Development.

Received for publication 16 August 1983.

Accepted for publication 20 September 1983. well as partial monosomy ${ }^{4}$ and trisomy ${ }^{5}$ for $18 \mathrm{q}$. We report a patient with a typical trisomy 18 phenotype who had an isopseudodicentric chromosome 18.

\section{Case report}

The proband was the $2.4 \mathrm{~kg}$ product of a 42 week gestation to a 20 year old G1 mother and her 21 year old husband. Breech presentation prompted a caesarean section delivery. At birth, an omphalocele and multiple dysmorphic features were noted. Examination (fig 1) in the nursery showed the weight and length $(42 \mathrm{~cm})$ to be below the $3 \mathrm{rd}$ centile for age. Examination of the head showed a circumference of $33 \mathrm{~cm}$ (5th centile), a prominent occiput, and low set, poorly formed ears. The face had a short nose, short palpebral fissures $(1.75 \mathrm{~cm})$, and micrognathia. Abnormalities of the chest and 


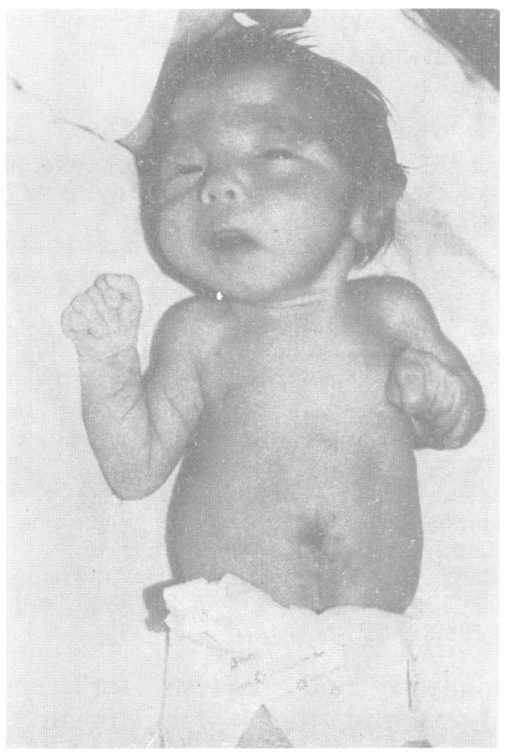

FIG 1 Paticnt at one month showing characteristic facial features, fisting of hands, and omphalocele scar.

abdomen consisted of a short sternum $(4 \cdot 5 \mathrm{~cm})$, a harsh systolic murmur, and a large omphalocele. Examination of the extremities showed limited hip abduction, hypoplastic second toes, the outer fingers overlapping the middle fingers, a single transverse palmar crease, clinodactyly of the fifth fingers, and six simple arch patterns on the fingertips. In addition to generalised hypertonia, there were poor suck and Moro reflexes.

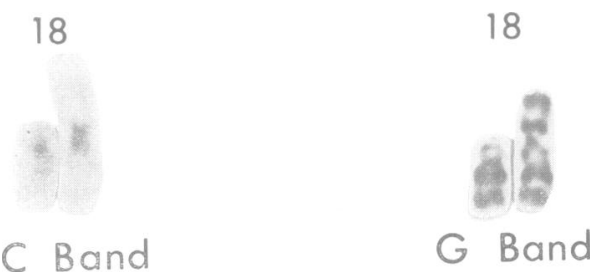

FIG 2 Chromosome 18 with the isopseudodic(18).

CYTOGENETIC STUDIES

Leucocyte chromosomes from a venous blood sample studied with $\mathrm{G}$ and $\mathrm{C}$ bands revealed 46,XX,-18, +-isopseudodic(18)(p11) (fig 2). G N banding of the isopseudodic(18) showed only a iv single constriction, but with $\mathrm{C}$ banding (fig 2) two positive staining regions with a small amount of short arm material between them were seen. Both parental karyotypes were normal.

\section{Discussion}

We believe that the phenotypes (table) described with the major structural abnormalities of chromosome 18 are sufficiently distinct to allow phenotypegenotype associations. An example of this association is illustrated by the report of Bass $e$ a $^{6}{ }^{6}$ of a patient with isochromosome (18q) who had phenotypic features of both trisomy 18 and $18 \mathrm{p}-$. Their patient's karyotype had a single centromere on the iso(18); therefore, he was trisomic for $18 \mathrm{q}$ and monosomic for $18 \mathrm{p}$. Our patient, who is trisomic for $18 \mathrm{q}$ and $18 \mathrm{p} 11$ with monosomy for $18 \mathrm{p} 12 \rightarrow$ pter, has a phenotype which is typical of trisomy 18 . Since no features of the $18 \mathrm{p}-$ syndrome were seen, we

TABLE Clinical features of chromosome 18 abnormalities.

\begin{tabular}{|c|c|c|c|c|c|}
\hline & Triscmy 18 or $18 q$ & $\begin{array}{l}\text { Monosomy } 18 q \\
\text { (partial) }\end{array}$ & Monosomy $1 \varepsilon p$ & Trisomy $18 p$ & Tetrasomy $18 p$ \\
\hline Birth weight & Low & Low & Low & Normal & Normal to low \\
\hline $\begin{array}{l}\text { Developmental } \\
\text { retardation }\end{array}$ & Severe & Severe & Moderate & Variable & Moderate to severe \\
\hline Cranium & $\begin{array}{l}\text { Prominent occiput, } \\
\text { microcephaly }\end{array}$ & Microcephaly & Microcephaly (mild) & Normal & $\begin{array}{l}\text { Prominent occiput, } \\
\text { microcephaly }\end{array}$ \\
\hline Eyes & $\begin{array}{l}\text { Short palebral } \\
\text { fissures }\end{array}$ & $\begin{array}{l}\text { Nystagmus, deep } \\
\text { set eyes }\end{array}$ & $\begin{array}{l}\text { Epicanthal folds, } \\
\text { ptosis }\end{array}$ & Normal & Not noted \\
\hline Ears & $\begin{array}{l}\text { Low set, poorly } \\
\text { formed }\end{array}$ & $\begin{array}{l}\text { Prominent antihelix } \\
\text { and antitragus }\end{array}$ & $\begin{array}{l}\text { Large, floppy, } \\
\text { low set }\end{array}$ & Normal & Low set \\
\hline Nose & Short, upturned & Flat bridge & Flat bridge & Flat bridge & Short, pinched \\
\hline Palate & Narrow & Narrow & Variable & Normal & High arched \\
\hline Jaw & Micrognathia & Prominent & Micrognathia & Normal to small & Micrognathia \\
\hline Neck & Short & Not characteristic & Webbed, short & Normal & Normal \\
\hline Heart & VSD, PDA & Occasional defects & Rare defects & Normal & Normal \\
\hline Extremities & $\begin{array}{l}\text { Overlapping fingers, } \\
\text { dislocated hips, } \\
\text { prominent calcaneus }\end{array}$ & $\begin{array}{l}\text { Skin dimples over } \\
\text { joints, club foot }\end{array}$ & $\begin{array}{l}\text { Short hands and } \\
\text { fingers, lymphoedema }\end{array}$ & Normal & $\begin{array}{l}\text { Long thin limbs, } \\
\text { scoliosis }\end{array}$ \\
\hline Tone & Hypertonia & Hypotonia & Variable & Normal & Hypotonia \\
\hline Dermatoglyphs & $\begin{array}{l}6 \text { or more arches, } \\
\text { distal } t \text { triradius }\end{array}$ & Increased whorls & Not characteristic & Not characteristic & Not characteristic \\
\hline Other & $\begin{array}{l}\text { GI and renal anomalies, } \\
\text { early death }\end{array}$ & $\begin{array}{l}\text { Carp-shaped } \\
\text { mouth }\end{array}$ & $\begin{array}{l}\text { Turner-like } \\
\text { appearance }\end{array}$ & $\begin{array}{l}\text { Short stature, } \\
\text { round face }\end{array}$ & Carp-shaped mouth \\
\hline
\end{tabular}


conclude that the Turner-like features associated with $18 \mathrm{p}-$ may be determined by monosomy for $18 \mathrm{p} 11$.

Abnormalities of the short arm of chromosome 18 show distinctive phenotypes depending on the number of copies of this area present (table). Monosomy $18 \mathrm{p}$ has a Turner-like phenotype with moderate mental retardation. Interestingly, trisomy $18 \mathrm{p}$ shows little phenotypic effect and mental development has ranged from normal ${ }^{2}$ to mildly delayed. ${ }^{7}$ Tetrasomy $18 \mathrm{p}$ has severe phenotypic features including moderate to severe mental retardation, hypotonia, and multiple musculoskeletal anomalies.

Abnormalities of $18 \mathrm{q}$ have greater phenotypic effects. Complete monosomy of $18 \mathrm{q}$ has not been described, but a fairly consistent phenotype (table), which includes severe mental retardation, has been reported in partial $18 \mathrm{q}-$. Patients who are trisomic for $18 \mathrm{q}$ and disomic for $18 \mathrm{p}$ have a typical trisomy 18 phenotype, indicating that only trisomy $18 \mathrm{q}$ is required for full expression of this phenotype. ${ }^{5}$

Formation of isodicentric chromosomes is poorly understood. If formation occurs during mitotic or first meiotic division, it would result in a derivative chromosome with non-identical arms and centromeres. However, formation during second meiotic division would result in identical arms and centromeres. We are not aware of chromosome 18 polymorphism or polymorphic gene markers that would allow us to choose among these options. The majority of reported dicentric chromosomes have had only one active centromere. ${ }^{8}$ We currently do not understand the centromere inactivation process. Possibly, suppression of one centromere results in a more stable structure that is better able to undergo cell division.
Our report of an isopseudodicentric(18) associated with a trisomy 18 phenotype adds information to the correlation of phenotype and genotype in chromosome 18 abnormalities. Considering the vast phenotypic differences in normal subjects, it is not surprising that phenotypic variation exists in those with similar chromosome abnormalities. It is more remarkable that sufficient similarity exists among these patients to allow phenotype-genotype correlation.

\section{References}

1 de Grouchy J. The $18 \mathrm{p}-, 18 \mathrm{q}-$, and $18 \mathrm{r}$ syndromes. Birth Defects 1969;5:74-87.

2 Taylor KM, Wolfinger HL, Brown MG, Chadwick OL. Origin of a small metacentric chromosome: familial and cytogenetic evidence. Clin Genet $1975 ; 8: 364-9$.

3 Nielsen KB, Dyggve $\mathrm{H}$, Friedrich V, Hobolth $\mathrm{N}$, Lyngbye T, Mikkelsen M. Small metacentric nonsatellited extra chromosome: report of five mentally retarded individuals and review of literature. Hum Genet $1978 ; 44$ : 59-69.

4 de Grouchy J, Turleau CT. Clinical atlas of human chromosomes. New York: Wiley, 1977:170-6.

5 Hecht F, Bryant J, Arakaki D, Kaplan E, Gentile G. Trisomy-18 syndrome due to de-novo translocation. Lancet $1963 ; \mathrm{i}: 114$.

6 Bass HN, Sparkes RS, Miller AA. Features of trisomy 18 and $18 \mathrm{p}-$ syndromes in an infant with $46, \mathrm{XY}, \mathrm{i}(18 \mathrm{q})$. Clin Genet 1979;16:163-8.

- Jacobsen P, Mikkelsen M. Chromosome 18 abnormalities in a family with a translocation $5(18 \mathrm{p}-, 21 \mathrm{p}-)$. J Ment Defic Res 1969;12:144-61.

8 Madan K, Vlasveld L, Barth PG. Ring-18 and isopseudodicentric-18 in the same child: a hypothesis to account for common origin. Ann Genet (Paris) 1981 ;24: $12-6$.

Correspondence and requests for reprints to $\mathrm{Dr}$ Robert S Sparkes, Department of Medicine, UCLA School of Medicine, Los Angeles, California 90024, USA.

\title{
A genetic combination of silent $\beta$-thalassaemia, high $\mathrm{Hb} \mathrm{A_{2 }}$ $\beta$-thalassaemia, and single $\alpha$ globin gene deletion causing mild thalassaemia intermedia
}

\author{
R GALANELlo, L MACCIONi, M C ROSATELli, P IBBA*, \\ A M NURCHI*, AND A CAO \\ Istituto di Clinica e Biologia dell'Età Evolutiva, and *Clinica Pediatrica, \\ Università degli Studi di Cagliari, Sardinia, Italy.
}

SUMMARY This paper reports a Sardinian patient, who was a compound heterozygote for silent $\beta$-thalassaemia and high $\mathrm{Hb} \mathrm{A}_{2} \beta^{\circ}$ -

Received for publication 18 June 1983.

Accepted for publication 3 August 1983. thalassaemia with the clinical phenotype of mild thalassaemia intermedia; $\alpha$ globin gene mapping showed a single $\alpha$ globin gene deletion. The reduced $\alpha$ globin chain output resulted in more balanced globin chain synthesis, which in turn accounted for the mild clinical phenotype. 